University of Nebraska - Lincoln

DigitalCommons@University of Nebraska - Lincoln

2016

Pranked by Audubon: Constantine S. Rafinesque's description of John James Audubon's imaginary Kentucky mammals

Neal Woodman

Follow this and additional works at: https://digitalcommons.unl.edu/usgsstaffpub

Part of the Geology Commons, Oceanography and Atmospheric Sciences and Meteorology Commons, Other Earth Sciences Commons, and the Other Environmental Sciences Commons

This Article is brought to you for free and open access by the US Geological Survey at DigitalCommons@University of Nebraska - Lincoln. It has been accepted for inclusion in USGS Staff -- Published Research by an authorized administrator of DigitalCommons@University of Nebraska - Lincoln. 


\title{
Pranked by Audubon: Constantine S. Rafinesque's description of John James Audubon's imaginary Kentucky mammals
}

\author{
NEAL WOODMAN \\ USGS Patuxent Wildlife Research Center, MRC-111, National Museum of Natural History, Smithsonian \\ Institution, P.O. Box 37012, Washington, DC 20013-7012 USA (email: woodmann@si.edu).
}

\begin{abstract}
The North American naturalist Constantine S. Rafinesque spent much of the year 1818 engaged in a solo journey down the Ohio River Valley to explore parts of what was then the western United States. Along the way, he visited a number of fellow naturalists, and he spent more than a week at the Henderson, Kentucky, home of artist and ornithologist John James Audubon. During the succeeding two years, Rafinesque published descriptions of new species that resulted from his expedition, including eleven species of fishes that eventually proved to have been invented by Audubon as a prank on the credulous naturalist. Less well known are a number of "wild rats" described by Rafinesque that include one recognized species (Musculus leucopus) and ten other, imaginary "species" fabricated by Audubon (Gerbillus leonurus, G. megalops, Spalax trivittata, Cricetus fasciatus, Sorex cerulescens, S. melanotis, Musculus nigricans, Lemmus albovittatus, L. talpoides, Sciurus ruber). Rafinesque's unpublished sketches of these animals provide important insight regarding the supposed nature of the animals invented by Audubon and ultimately published by Rafinesque.
\end{abstract}

KEY WORDS : cryptozoology - eccentric naturalist - hoax - mouse - Peromyscus leucopus - Sciurus niger rufiventer.

\section{INTRODUCTION}

On 25 November 1818, two days after arriving in Philadelphia, the naturalist, Constantine S. Rafinesque (1783-1840), wrote to his sister in France, "Now I am back from a long Trip of 7 months in the interior of the United States: I traveled more than 2,500 miles (or more than 850 leagues) round trip, half of which I did on foot!"1 Beginning his journey at the end of April 1818, Rafinesque left New York City for the western territories, hoping to travel as far west as the Mississippi River. ${ }^{2}$ He went overland to Philadelphia and Pittsburgh, Pennsylvania, then descended the Ohio River by boat, visiting the states of Ohio, Indiana and Kentucky and eventually travelling as far west as the town of Carmi in the Illinois Territory (Woodman 2015). Along the way, he visited a number of fellow naturalists, inspecting their herbaria and collections and sometimes botanizing with them (Rafinesque 1836). Among the colleagues he called on was the ornithologist and artist John James Audubon (1785-1851), who was living on the Ohio River in Henderson, Kentucky (Audubon and Audubon 1868).

A knowledgeable field botanist (Pennell 1942) and an early evolutionist (Call 1895; Ambrose 2010), Rafinesque tended to focus on plants, molluscs and fishes, although his interests encompassed all types of organisms including fossils. He was also a prolific 
describer of new taxa, eventually naming around 2,700 genera and 6,700 species of plants alone (Merrill 1949). Not surprisingly, Rafinesque took great interest in the variety of living and fossil organisms he encountered throughout his western trip. As his journey progressed, Rafinesque sent reports of his discoveries back east to his scientific correspondents, and he spent the next few years publishing formal descriptions of many of the new taxa he discovered (see, for example, Rafinesque 1818a, 1818b, 1818c, 1818d, 1819a, 1819b, 1819c, $\left.1820 \mathrm{a}, 1820 \mathrm{~b}, 1820 \mathrm{c}, 1820 \mathrm{~d}, 1820 \mathrm{~d}, 1820 \mathrm{f}, 1820 \mathrm{~g}^{3}\right)$. In a letter written shortly after his trip to the French naturalist Baron Georges Cuvier, Rafinesque boasted ${ }^{4}$,

I discovered $40 \mathrm{~N}[\mathrm{ew}$ ]. G[enera]. of living Animals and more than $300 \mathrm{~N}[\mathrm{ew}]$. Sp[ecies]!, about 30 N. G. and 150 N. Sp. of fossil animals!, 12 N. G. and 120 N. Sp of plants that I collected and brought back here more than half of them, all at my own expense!

Rafinesque had a wealth of living organisms, specimens and personal observations with which to work during his journey, but in his quest to document the biotic diversity of the western United States, he also relied upon the observations of local inhabitants. Among the new fishes that he named, for example, were 17 species that he had never seen and whose ascribed characteristics were based on the accounts of other individuals or, in two cases, on general hearsay (Rafinesque 1820g: 52, 61, 86-87; Markle 1997). Audubon proved to be a particularly rich source of new species, providing information and even sketches for at least eleven fishes (Rafinesque 1820g) (Table 1). ${ }^{5}$ Unfortunately, as later ichthyologists discovered (Jordan 1877b: 6), these fishes "were drawn by Audubon with a view to a practical joke on the too credulous ichthyologist." 6 That is, Audubon invented imaginary fishes and described them to the trusting Rafinesque, who, believing them to be real, published formal descriptions of them. Although Rafinesque expressed doubts about a couple of the species described to him by Audubon, his concerns regarded the accuracy of Audubon's renderings rather than the species' existence ${ }^{7}$, and he was not so cautious as to omit them from his manuscripts.

Fortunately, Rafinesque openly attributed these eleven species to Audubon in his compendium of Ohio River fishes, Ichthyologia Ohiensis. There is evidence, however, that there were other invented "species". Markle (1997), for example, questioned the veracity of three additional fish species that he surmised had originated with Audubon but were not acknowledged as such by Rafinesque (Table 1). And, while Audubon's unorthodox fishes have received considerable attention in the scientific and popular press (Jordan 1877a, 1877b; Call 1899; Markle 1997; Gilbert 1999), other organisms were involved in Audubon's ruse as well, including at least two birds, a "trivalved" brachiopod or mollusc-like creature ${ }^{8}$, three snails ${ }^{9}$ (Rafinesque 1819b, 1819c, 1820b; see also Lea 1870; Pilsbry 1917; Petit 1985), and two plants ${ }^{10}$ (Table 1). In one of the papers in which he originally described some of Audubon's invented fishes, Rafinesque (1818b: 446) also described ten "wild rats of the western states", a list that includes both real and imaginary species. Using unpublished sketches and descriptions, and with the advantages of hindsight and a more comprehensive knowledge of the mammalian fauna of Kentucky, I address the "wild rats" and show that Audubon's prank on Rafinesque extended to a larger number of taxa than generally realized.

\section{RAFINESQUE'S NOTEBOOK AND OTHER SOURCES}

Rafinesque's publications resulting from his western trip provide a starting point for understanding his new species. In addition to the original descriptions of his "wild rats" 
Table 1. List of fantastic animals described by Rafinesque based on descriptions and sketches by Audubon. Notes indicate species directly attributed to Audubon by Rafinesque in one of his publications (column A); the fieldbook entry number (column B); the species number in Ichthyologia Ohioensis (Rafinesque 1820g) (column C); and whether there is a sketch of the animal in Rafinesque's field notebook (column D).

Original published name

Brachiopod

Notrema fissurella Raf. 1819b:356

Molluscs

Espiphylla nympheola Raf. 1819c:424

Lomastoma terebrina Raf. 1819c:424

Eutrema terebroides Raf. 1819c:424

Fishes

Perca nigropunctata Raf. 1820a:371

Bodianus calliops Raf. 1818b:447

Pogostoma leucops Raf. 1818b:447

Catostomus anisopturus Raf. 1820d:301

Amblodon niger Raf. 1819c:421

Catostomus fasciolaris Raf. 1820d:304

Catostomus? megastomus Raf. 1820d:306

Pylodictis limosus Raf. 1819c:422

Esox vittatus Raf. 1818b:447

Esox salmoneus Raf. 1820e:167

Litholepis adamantinus Raf 1818b:447

Anguilla laticauda Raf. 1818b:447

Accipenser macrostomus Raf. 1820f:249

Dinoctus truncates Raf. 1818b:447

Birds

Charadrius viridis Raf. 1820b:4

Hirundo phenicephala Raf. 1820b:4

Mammals

Gerbillus megalops Raf. 1818b:446

Gerbillus leonurus Raf. 1818b:446

Spalax trivittata Raf. 1818b:446

Cricetus fasciatus Raf. 1818b:446

Sorex melanotis Raf. 1818b:446

Sorex cerulescens Raf. 1818b:446

Musculus nigricans Raf. 1818b:446

Lemmus talpoides Raf. 1818b:446

Lemmus albovittatus Raf. 1818b:446

Sciurus ruber Raf. 1820b:4 common name

Tri-valve

snail

snail

snail

Black dotted perch

Bride perch, red-Eye

Barbot, pogostoma

Buffalo carp sucker

Black buffalo-fish

Rough-head sucker

Big-mouth sucker

Toad mudcat

Streaked pike

Salmon pike

Diamond fish

Broadtail eel

Bigmouth sturgeon

Double fin

Green plover

Red-headed swallow

Big-eye jumping mouse

Lion-tail jumping mouse

Three-striped mole rat

Brindled stamiter

Black-eared shrew

Bluish shrew mouse

Blackish rat

Mole lemming

White-striped lemming

Great fox squirrel

$\begin{array}{cccc}\text { A } & \text { B } & \text { C } & \text { D } \\ \checkmark & 26 & - & \checkmark \\ & & & \\ - & - & - & - \\ - & - & - & - \\ - & 25 & - & \checkmark\end{array}$

$\checkmark \quad 216 \quad 3$

$\checkmark \quad 215 \quad 19$

$\checkmark \quad 197 \quad 20$

$\checkmark \quad 144 \quad 54$

$\checkmark \quad 58 \quad 56$

$\checkmark \quad 222 \quad 62$

$\checkmark \quad-\quad 65$

$\checkmark \quad 147 \quad 80$

- $145 \quad 84$

- $185 \quad 85$

$\checkmark \quad 143 \quad 91$

- $223 \quad 92$

$\checkmark \quad 142 \quad 100$

141

101

$\begin{array}{llll}- & 187 & - & \checkmark \\ - & 191 & - & \checkmark \\ \checkmark & 186 & - & \checkmark \\ - & 193 & - & \checkmark \\ - & 194 & - & \checkmark \\ - & - & - & - \\ - & 224 & - & \checkmark \\ - & 225 & - & - \\ - & 192 & - & \checkmark \\ - & 228 & - & -\end{array}$


(Rafinesque 1818b), Rafinesque re-described - and occasionally renamed - a number of these species (for example, Rafinesque 1820b, 1820g). Although this was poor taxonomic practice even at that time, the secondary descriptions can be useful for providing details omitted from the earlier descriptions.

Although it has been implied that Rafinesque drew mostly upon his memory for details of organisms he encountered (Jordan 1886), Audubon (1831: 456) indicated otherwise: "When we returned home, the naturalist opened the bundle which he had brought on his back, and took out a journal rendered water-proof by means of a leather case, together with a small parcel of linen, examined the new plant, and wrote its description." Rafinesque's field notebook from his 1818 western journey is extant ${ }^{11}$, and includes sketches and descriptions in French of many (but not all) of the taxa he subsequently described in print, as well as itineraries of his travels and hand-drawn maps. Some of Rafinesque's published descriptions are close translations of his original French descriptions in the field notebook, although there are also additions and omissions. The notebook is unpaginated, and its pages were filled in no particular order, although groups of descriptions on the same and sometimes adjacent pages often have a common theme and appear to be contemporaneous. Many entries were originally written in pencil and later written over in ink. Most species accounts are numbered in order from 1 to 267. Although these numbers appear to have been written subsequently in a hand other than Rafinesque's, they provide a convenient means of reference (Table 1).

Rafinesque's correspondence during and after his journey helps with understanding the timing of his travel and the locations of his discoveries. Woodman (2015) provided a reconstructed itinerary and map of a relevant portion of Rafinesque's western trip.

Rafinesque's visit to Henderson, where he met and stayed with Audubon, served as the inspiration for Audubon's (1831: 455-460) humorous tale "The eccentric naturalist". Although that story was probably embellished for entertainment value, Rafinesque's subsequent publications lend credence to the underlying events, and it provides details that are otherwise undocumented.

\section{RAFINESQUE'S VISIT WITH AUDUBON}

Rafinesque arrived in Henderson from Louisville, Kentucky, by keelboat, probably between 29 July and 4 August 1818 (Woodman 2015). He met Audubon with a letter of introduction from a mutual acquaintance ${ }^{12}$ (Audubon 1831) and was invited to stay in the Audubons' home, where he remained for eight days, according to Rafinesque, or three weeks, according to his host (1831). ${ }^{13}$ Rafinesque's estimate seems closer to the truth on this point, as it is known that he left the Audubon home on 12 August $^{14}$ and went to Mr Alvis's house on the outskirts of Henderson. He stayed there two days on account of rain, before leaving on a horse borrowed from Alvis for an excursion across the Ohio River to Indiana and Illinois (Woodman 2015).

Jordan (1886: 217; see also Markle 1996) ${ }^{15}$ considered that Audubon's invention and communication of the fantastic animals to Rafinesque may have been a mischievous form of "revenge" stemming from the "violin incident" during the first night he stayed with the family, an event communicated by Audubon (1831: 457):

We had all retired to rest. Every person I imagined was in deep slumber save myself, when of a sudden I heard a great uproar in the naturalist's room. I got up, reached the place in a few moments, and opened the door, when, 
to my astonishment, I saw my guest running about the room naked, holding the handle of my favourite violin, the body of which he had battered to pieces against the walls in attempting to kill the bats which had entered by the open window, probably attracted by the insects flying around his candle. I stood amazed, but he continued jumping and running round and round, until he was fairly exhausted, when he begged me to procure one of the animals for him, as he felt convinced they belonged to "a new species." Although I was convinced of the contrary, I took up the bow of my demolished Cremona, and administering a smart tap to each of the bats as it came up, soon got specimens enough. The war ended, I again bade him good night, but could not help observing the state of the room. It was strewed with plants, which it would seem he had arranged into groups, but which were now scattered about in confusion. "Never mind, Mr Audubon," quoth the eccentric naturalist, "never mind, I'll soon arrange them again. I have the bats, and that's enough.

The veracity of the event that served as the basis for the violin story is supported by the new species of bats that Rafinesque (1818b) subsequently named and described from his trip to Henderson. ${ }^{16}$ Whether or not it was payback for his broken violin, Audubon's subsequent relation of the fantastic animals was certainly in line with his sense of humour ${ }^{17}$ and may have been meant to test the limits of Rafinesque's gullibility, or, possibly, his sanity. Although Audubon described Rafinesque as "a most agreeable and intelligent companion and hoped his sojourn [with us] might be of long duration" (Audubon 1831: 460), he also noted with some humour Rafinesque's arrogant condescension ${ }^{18}$, and Audubon later termed Rafinesque "crazy". 19

The violin story and other events narrated in "The eccentric naturalist" provide insight into Audubon's view of Rafinesque's behaviour and his obsession with the discovery and documentation of new genera and species, two characteristics of Rafinesque's personality that are otherwise well documented (Call 1895; Merrill 1949; Boewe 2011a). Audubon (1831: 456) noted that Rafinesque "had come to visit me, he said, expressly for the purpose of seeing my drawings, having been told that my representations of birds were accompanied by those of shrubs and plants, and he was desirous of knowing whether I might chance to have in my collection any with which he was unacquainted." Rafinesque was on the hunt for new species, and Audubon did not disappoint him.

\section{AUDUBON'S FANTASTIC KENTUCKY MAMMALS}

At Henderson on 12 August 1818, Rafinesque wrote the first half of a letter summarizing his recent discoveries, including the "10 new species of Rats or Mice" ${ }^{20}$ for which he subsequently published formal descriptions in the October issue of American monthly magazine and critical review (Rafinesque 1818b). This letter establishes that Rafinesque knew of these species before his departure from Henderson. In fact, one species, the white-footed mouse (Musculus leucopus = Peromyscus leucopus), was recorded at Shippingport, Kentucky, before Rafinesque's visit with Audubon (Woodman 2015); this is also the only species among the ten that is recognizable as a real entity. The remaining nine species of "wild rats" were dismissed without further discussion by later mammalogists as "imaginary" (Baird 1857: 459) and "absolutely 'impossible' species" (Osgood 1909: 116).

Unlike Audubon's imaginary fishes, Rafinesque was not forthcoming about the source of his mammals. Among the nine "wild rats" that derived from his trip to Henderson, Rafinesque acknowledged only one species as originating with Audubon and that was not until 14 years after he first described it (Rafinesque 1832). ${ }^{21}$ The descriptions of the mammals, however, are similar in many ways to those of the fishes (Markle 1996). Each has 
a general form that is recognizable, but also possesses certain characteristics or behaviours that set it apart and are not reconcilable with any known species. Several of the imaginary species clearly are similar to Old World taxa that do not occur in North America, but with which both Audubon and Rafinesque would have been familiar because of the naturalists' European ties. Eight of the "wild rats" are represented by accounts in two sections of Rafinesque's field notebook, and seven of the accounts are accompanied by sketches (Figures 1-7).

The first two species of "wild rats" named and described by Rafinesque (1818b), the "Big-eye jumping mouse" (Gerbillus megalops) (Figure 1) and the "Lion-tail jumping mouse" (Gerbillus leonurus) (Figure 2), were most probably modelled on Old World gerbils (for example, Gerbillus gerbillus), which typically have large eyes and can have a distinctive tuft of hair at the tip of the tail. The Kentucky species they most closely resemble in general form is the meadow jumping mouse (Zapus hudsonius), which was classified at that time as a species of jerboa (Dipus: see, for example, Ord 1815; Coues 1876). In his field notebook, Rafinesque originally had both species listed as Dipus, but that name was later crossed out and the generic name Gerbillus substituted. The meadow jumping mouse, however, has much smaller eyes and ears, a shorter snout, and a more orange-brown coloration, and Preble (1899) discounted the possibility of either of Rafinesque's species being a jumping mouse. Further indication that Rafinesque's descriptions derived from a source other than his own observations is his notation that the big-eye jumping mouse was found in the "barrens of Kentucky" (Rafinesque 1818b: 446), a region he did not visit until after he left Henderson (Woodman 2015).

Another species, the "Three-striped mole rat" (Spalax trivittata) (Figure 3), was modeled on the greater blind mole rats (Spalax) that occur in the general region around the eastern Mediterranean and the Black and Caspian seas of Eurasia. This animal is not confusable with any North American mammal. The closest in general form would be a gopher, such as the Plains pocket gopher (Geomys bursarius), which has a short tail (rather than no tail), but which also does not occur in Kentucky. The striped pattern on the back of the "Three-striped mole rat" would be unique for a burrowing small mammal.

Audubon most probably fashioned the "Brindled stamiter" (Cricetus fasciatus) (Figure 4) from the Eurasian hamster (Cricetus cricetus), but gave it a longer tail and a unique striped pattern on its back, tail and legs. The internal cheek pouches are shown inverted as external cheek pouches, which suggests Rafinesque's lack of familiarity with the living animal. There is nothing like the "Brindled stamiter" in the North American fauna.

Rafinesque (1818b) described two shrews, the "Black-eared shrew" or "Corn mouse" (Sorex melanotis) (Figure 5) and the "Bluish shrew mouse" (Sorex cerulescens) ${ }^{22}$, but only the former appears in his field notebook. The long snout and long, low body shown in Rafinesque's illustration of S. melanotis (Figure 5) are suggestive of a shrew, but the prominent ears noted for both species set them apart from North American soricids, in which the ears are small and typically hidden by the fur. Details of the coloration similarly distinguish these two species from any Kentucky shrew. If Audubon's later work is any indication, he certainly was familiar with North American shrews (Audubon and Bachman 1845-1854). Rafinesque, in contrast, appears to have had a weaker understanding of mammals, and shrews presented a particular problem for him. In his contemporary correspondence $^{23}$, he confused one of his lemmings with a shrew, and he subsequently named a new species of shrew (Rafinesque 1833) based on a specimen of a meadow jumping mouse (Woodman 2012). 

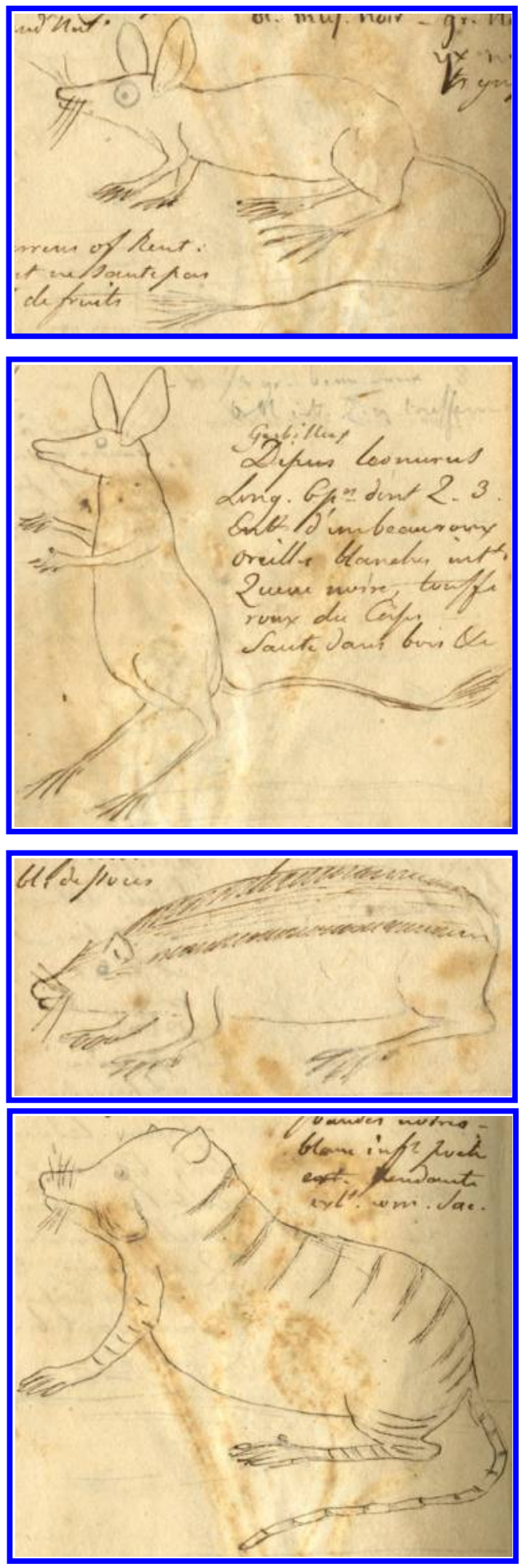

Figure 1. "Big-eye jumping mouse", Gerbillus megalops (Rafinesque's field notebook, no. 187). "Body gray, belly white, eyes black, very large, ears very long, white inside, snout black, tail longer than the body, black with a white tuft at the end. Total length 5 inches, body only 2 inches, in the barrens of Kentucky, \&c" (Rafinesque 1818b: 446). Rafinesque (1820a: 3) added: ". . . it feeds on seeds and fruits; total length six inches, of which the tail composes more than half." Original image $70 \times 48 \mathrm{~mm}$.

Figure 2. "Lion-tail jumping mouse", Gerbillus leonurus (no. 191). "Body fallow, ears very long, white inside, tail as long as the body, black, with a fallow tuft at the end. Length 6 inches, body 3 (Rafinesque 1818b: 446). "It rather jumps than runs, while the foregoing species [Gerbillus megalops] is oftener seen running than jumping" (Rafinesque 1820a: 3). Original image $80 \times$ $75 \mathrm{~mm}$.

Figure 3. "Three-striped mole rat", Spalax trivittata (no. 186). "Body fallow, with 3 large brown stripes above, white underneath, ears small, acute. Length 7 inches without any tail. In the woods, near brooks, \&c" (Rafinesque 1818b: 446). Rafinesque (1820a: 3) redescribed this as Spalax vittatta, adding "it burrows like a mole and feeds on snails, slugs, earthworms, \&c. It has almost the shape of a pig, but the snout is rounded and with small whiskers." This is the only species of mammal for which Rafinesque (1832) acknowledged Audubon as the source. Original image $57 \times 27 \mathrm{~mm}$.

Figure 4. "Brindled stamiter", Cricetus fasciatus (no. 193). "Body fallow, brindled, with black on the back, white underneath, legs and tail ringed of black, tail twofifths of total length, ears oval, acute, pouches hanging outside as bags. Length 8 inches. It burrows in the barrens" (Rafinesque 1818b: 446). Rafinesque (1820a: 3) provided a more detailed description: "Rufous, with about ten transversal black streaks over the back, legs with some similar streaks; tail rather shorter than the body, slender and with black ring: pouches external, flaccid. - This is the Hamster of the barrens of Kentucky and the western states; it has a thick body, the head like a dog, small eyes and ears, these oval and acute, the forehead rounded and the pouches hanging like bags." Original image $78 \times 68 \mathrm{~mm}$.

All images pen-over-pencil sketches from Rafinesque's field notebook 17. Images (SIA2012-6095, -6096) by courtesy of the Smithsonian Institution Archives, Washington, DC. 

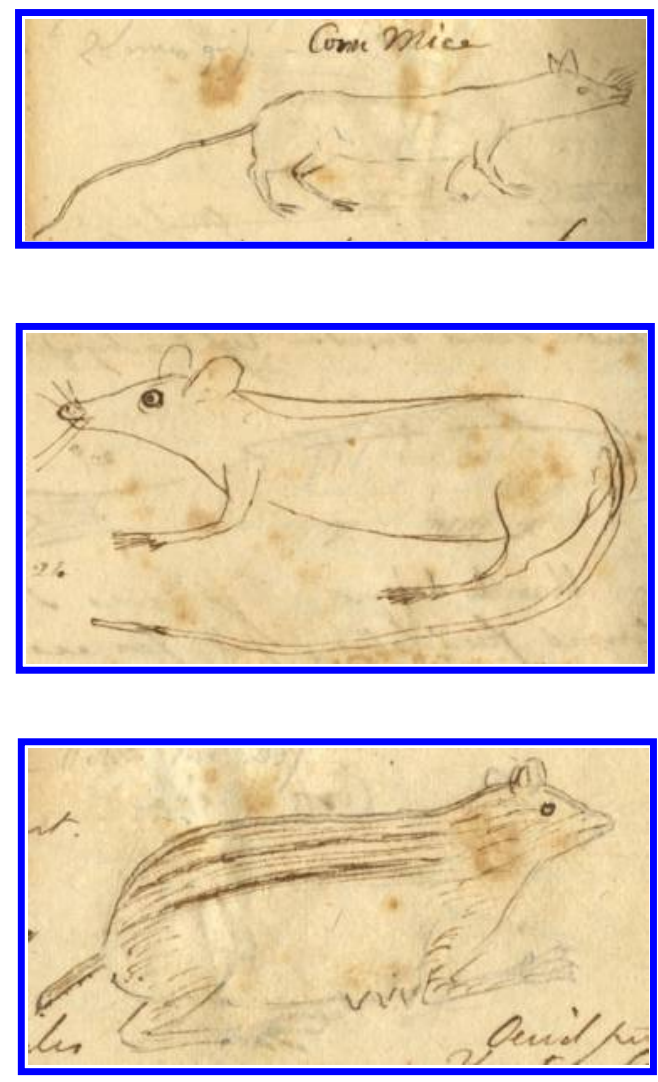

Figure 5. "Black-eared shrew," Sorex melanotis (no. 194). "Body pale gray, white beneath, ears erect, black outside, white inside, neck and body elongated, tail nearly as long, gray. Length 5 inches. Vulgar name, corn mice" (Rafinesque 1818b: 446). Original image $83 \times 24 \mathrm{~mm}$.

Figure 6. "Blackish rat Musculus niger", Musculus nigricans (no. 224). "Entirely blackish, belly gray, tail longer than the body and black. Length 6 inches. Common name, black rat or wood rat, lives in woods on seeds and nuts" (Rafinesque 1818b: 446). Original image $69 \times 36 \mathrm{~mm}$.

Figure 7. "White-striped lemming", Lemmus albovittatus (no. 192). "Fallow, with 5 white longitudinal stripes, the middle one extending over the head to the nose, tail truncate, one-sixth of total length. Length 4 inches. A most interesting small animal; vulgar name, nursing mouse. The female carries her young on her back, she has 6 pectoral teats; she lives on corn, seeds, \&c" (Rafinesque 1818b: 446). Formally described as L. albovittatus, Rafinesque (1818b: 106; 1820a: 3) subsequently referred to it as L. vittatus. Original image $57 \times 29 \mathrm{~mm}$.

All images pen-over-pencil sketches from Rafinesque's field notebook 17. Images (SIA2012-6095, -6096, -6099) by courtesy of the Smithsonian Institution Archives, Washington, DC.

As noted previously, the "White feet mouse" (Musculus leucopus), which was the seventh species of "wild rat" described by Rafinesque, is recognized today as a valid species (Peromyscus leucopus). Audubon had no hand in the description of this species, because Rafinesque discovered this mouse in Shippingport, Kentucky, before he reached Henderson (Woodman 2015). There is no mention of this species in his extant field notebook.

The eighth species is the "Blackish rat" (Musculus nigricans) (Figure 6). The sketch and description of this animal could correspond to a house mouse (Mus musculus). In fact, Musculus was Rafinesque's replacement name for the genus name Mus (Rafinesque 1814). Alternatively, this may have been a young rat black rat (Rattus rattus). Either animal may have added a dimension to the prank - what better way to test Rafinesque's trusting gullibility when it came to his compulsive need to name new species than to describe to him a common house pest (and an Old World species) as though it were something distinctive?

The last two species of "wild rats" were described by Rafinesque as species of Lemmus, a genus that encompasses some of the subarctic and arctic microtine rodents commonly referred to as lemmings (for example, Desmarest 1822: 286), but that do not occur in Kentucky. The "Mole lemming" (Lemmus talpoides) ${ }^{24}$ was not sketched. Although its form could be that of a small vole (Microtus), the coloration does not match any Kentucky species, and, while voles dig and form surface runways, they do not burrow to the extent that moles do. Rafinesque's 
"White-striped lemming" (Lemmus albovittatus) (Figure 7) is a tiny vole-like creature with a colour pattern reminiscent of an African striped grass mouse (Lemniscomys), but no creature like this is known among the rats and mice of North America. Its alleged behaviour of carrying it young on its back would be unique among small rodents.

One other species of mammal in the notebook, the "Great fox squirrel" (Sciurus ruber $)^{25}$, was not described until two years later (Rafinesque 1820b). Sciurus ruber is currently considered a junior synonym of S. niger rufiventer É. Geoffroy St-Hilaire (Hall 1981), a subspecies of the eastern fox squirrel found in the American midwest and northern Great Plains states. Rafinesque (1820b: 4) noted that "It is found in the Missouri Territory." However, he never crossed the Mississippi River and never visited the Missouri River drainage (Woodman 2015). Moreover, the coloration he described does not match the typical grizzled back and rufous belly of that form of fox squirrel. It is probable that this was one more description that Rafinesque obtained from another source, and Audubon is one of the most likely possibilities.

We know without doubt that Audubon provided Rafinesque with the description of one imaginary mammal, and it appears that he described nine additional "species" to him. This rivals in magnitude the number of fraudulent fishes he invented. Audubon may have thought that Rafinesque would realize the prank, and he probably considered it unlikely that the eccentric naturalist would be capable of publishing his descriptions in scientific journals. If so, he underestimated both Rafinesque's trusting naïveté and his ingenuity in finding and creating outlets for his work. ${ }^{26}$

\section{EPILOGUE}

Once when Spencer Fullerton Baird was visiting the American Museum of Natural History in New York, he and Charles Frederick Holder (1910: 272-273)

... were discussing taxidermy with John [Graham] Bell, the friend and companion of Audubon; Bell was telling his experiences with the great naturalist and how he almost had a serious break with him. Bell was traveling with Audubon, and every day new species were found; one day Bell said that he made up a bird with the head of a snipe, the body of something else, the wings and legs of another. Audubon had been away for a week, and when he returned Bell displayed the bird, saying that he had mounted it at once as it was in bad condition. Audubon was completely mystified and proportionately delighted. He described the new bird and sent the account to Europe, and it was weeks before Bell, then a young man, had the temerity to confess. When he did Audubon fell into a rage, but finally laughed, and acknowledged the cleverness of his assistant. $^{27}$

Hence, Audubon himself fell victim to a prank similar to the one he played on Rafinesque. To his credit, Audubon at least had a specimen in hand.

\section{ACKNOWLEDGEMENTS}

I thank the staff of the Smithsonian Institution Archives (SIA), Washington, D. C., for access to the documents under their care. Tad Bennicoff (SIA) provided permission to use the images from Rafinesque's notebook17 in Figures 1-7. My understanding of many of the animals described by Rafinesque benefited greatly from discussions with R. Terry Chesser, Kevin DeQuieroz, Alfred L. Gardner, Steve W. Gotte, Gary R. Graves, Harry W. Greene, Roy W. McDiarmid, Storrs L. Olson and Aleta Quinn. Any misinterpretations are my own. Alfred L. Gardner and Jennifer K. Frey provided substantive comments that greatly improved this manuscript.

Any use of trade, product or firm names is for descriptive purposes only and does not imply endorsement by the U. S. government. 


\section{NOTES}

${ }^{1}$ C. S. Rafinesque (hereafter CSR) to Georgette Louise Rafinesque Lanthois, 25 November 1818: "Me voici de retour d'un long Voyage de 7 mois, dans l'interieur des Etats Unis: J'ai voyagé plus de 2500 miles (ou plus de 850 lieues) en allant et en revenant, desquels < dont> j'ai fait la moitié à pied!" (Boewe (2011b: letter 130). English translations are also quoted from Boewe (2011b).

${ }^{2}$ C. S. Boewe, 2011 "The correspondence of C. S. Rafinesque": compact disc accompanying Boewe (2011) (hereafter Boewe 2011-CD): letter 130.

${ }^{3}$ Rafinesque's (1820g) book Ichthyologia Ohioensis is actually a subsequent compendium of ten articles on fishes of the Ohio River drainage that were published previously in three volumes (1819-1820) of Western review and miscellaneous magazine. Original descriptions of species date to those issues of the journal, or even earlier (for example, Rafineque 1818a, 1818b). However, it is convenient to be able to cite a single source for this material, which is why I do so here.

${ }^{4}$ CSR to Baron Georges Jean Léopold Nicolas Frédéric Cuvier, 28 December 1818, in Boewe 2011-CD: letter 131: "j'ai découvert 40 N. G. d'Animaux vivans et plus de 300 N. Esp! eviron 30 N. G. et 150 N. Esp. d'Animaux fossiles!, 12 N. G. et 120 N. Esp de Plantes! dont j'ai receuilli et apporté ici plus de la moitié, le tout à mes fraix!"

${ }^{5}$ In addition to Audubon, Rafinesque named species of fish based on accounts communicated to him by "Mr. Bollman of Pittsburgh", "Mr. Wilkins", "Mr. Owings" and "Mr. M- of St. Genevieve" (Rafinesque 1820g: 52, 61, 86-87; Markle 1997).

${ }^{6}$ The nature of Audubon's interaction with Rafinesque was recorded by Jordan (1886: 217): "The true story of this practical joke was told me by the venerable Dr. Kirtland, who in turn received it from Dr. Bachman, the brother-in-law and scientific associate of Audubon."

${ }^{7}$ Regarding the black dotted perch, Perca nigropunctata, for example, Rafinesque (1820g: 23) wrote: "I have not seen this species, I describe it from a drawing made by Mr. Audubon. I am therefore doubtful, whether it is a real perch, particularly since the drawing does not show the serratures and spines of the gill cover. It might be a Sciena, or a Dipterodon ...". Regarding the big-mouth Sucker ("Catostomus? megastomus"), he stated: "A very doubtful species seen by Mr. Audubon." But, again, his doubt was not in its existence, but in whether he allocated it to the correct genus, or if it might be a new genus, in which case, "It might be called Eurystomus" (Rafinesque 1820g: 60).

${ }^{8}$ Called "Notrema patelloides" in his field notebook (Smithsonian Institution Archives, Washington, DC.: SIA: RU 7250: Constantine Samuel Rafinesque papers, 1815-1834 and undated: Box 1: Folder 3-Book 17 (hereafter cited as SIA-RU 7250: 17) entry no. 26), the "trivalve" was originally described in print in March 1819 (Rafinesque $1819 b$ ) as Notrema fissurella. It was renamed Notrema patelloides in June 1819 (Rafinesque 1819c) and Tremesia patelloides in September 1820 (Rafinesque 1820c).

${ }^{9}$ All three snails (Espiphylla nympheola, Lomastoma terebrina, Eutrema terebroides) were described in Rafinesque (1819c). An illustration and account for the last species appears as "Eurystoma terebroides" (entry no. 25) in Rafinesque's field notebook on the same page as his "trivalve" (SIA-RU 7250: 17). Although not directly attributed to Audubon, Pilsbry $(1917$ : 113,114) judged all three snails to be either "imaginary" or "mythical".

${ }^{10}$ The two plants are illustrated in Rafinesque's field notebook (SIA-RU 7250: 17): Entry no. 182, "Tulipa montana" was annotated, "Mr. Audubon Allegh[eny] Valley May 1809"; and entry no. 183, "Yellow Paint of [the] Osage [River] ... Menispermum tinctorium?" was annotated, "Audub[on]. Iles des Mississ[ippi] et Missouri". Despite Rafinesque's predilection for botany, neither of these descriptions was published.

${ }^{11}$ SIA-RU 7250.

${ }^{12}$ According to Audubon (1831: 455), the sealed letter of introduction read "My dear Audubon, I send you a strange fish, which you may prove to be undescribed, and I hope you will do so in your next letter. Believe me always your friend B." In his autobiography, Audubon (Audubon et al., 1898,:1: 29) wrote of his early years in Kentucky, "Our most intimate friends were the Tarascons and Berthouds, at Louisville and Shippingport". The letter of introduction was most probably from a member of one of those two families. Louis and John Antoine Tarascon and James Berthoud, the Marquis de Saint Pierre, had fled the French Revolution and shared business interests in Shippingport, Kentucky, a commercial town that they founded. They shared with Audubon and Rafinesque the common bond of being native speakers of French (Kleber 1992: 819). Rafinesque (1836; see also Woodman 2015) stayed with the Tarascons in Shippingport just before travelling to Henderson, and he probably met the Berthouds during his visit. When Audubon asked to see the fish, Rafinesque reportedly 
replied, "I am that odd fish I presume, Mr. Audubon." If true, this shows considerable self-awareness on the part of Rafinesque.

${ }^{13}$ Boewe 2011-CD: letter 130. The duration of Rafinesque's stay in Henderson was probably somewhere in between his report of eight days and Audubon's three weeks. Rafinesque had written a letter from Shippingport, Kentucky, on 20 July, which is the earliest he could have left that town (CSR to Zaccheus Collins: Boewe 2011-CD: letter 123). The approximately 390-km trip down the Ohio River to Henderson required as many as nine days (Cramer 1817; Smith and Swick 1997), but it may have taken Rafinesque even longer, because the crew of the keelboat on which he took passage stopped to trade at settlements along the way, and he later wrote that he disembarked at Henderson because the boat travelled too slowly (Rafinesque 1836).

${ }^{14}$ SIA-RU 7250

15 Jordan (1886: 217) wrote:

Audubon was something of a wag withal, and some spirit of mischief led him to revenge the loss of his violin on the too ready credulity of his guest. He showed him gravely some ten grotesque drawings of impossible fishes which he had observed 'down the river,' with notes on their habits, and a list of the names by which they were known by the French and the English settlers. These Rafinesque duly copied into his note-books, and later he published descriptions of them ....

See also note 6 .

${ }^{16}$ Rafinesque (1818b) named nine bats from his western trip. One, the whisker bat (Vespertilio mystax), was discovered before he reached Henderson (Rafinesque 1818a). At least seven of the remaining eight, however, appear to have been encountered during his visit with Audubon, although only two are described in his field notebook. For one species, Vespertilio phaiops ( = Eptesicus fuscus), Rafinesque sketched and described minute details of the teeth, indicating that he had a specimen in hand. Regarding this species, Rafinesque (1820b: 3) subsequently stated, "It comes often in the house at night."

${ }^{17}$ Audubon's (1831: 310-312) merciless sense of humour is also on display in his story "The traveller and the pole-cat", in which he wrote about the time he convinced a naïve European visitor that a wild striped skunk was a friendly, easy-to-handle native squirrel. The consequences were to be expected: the "traveller" was sprayed by the animal, and the two of them subsequently had difficulty finding lodging.

${ }^{18}$ Audubon (1831: 456-457) wrote of Rafinesque: "You would be pleased, kind reader, to hear his criticisms, which were of the greatest advantage to me, for, being well acquainted with books as well as with nature, he was well fitted to give me advice."

19 On 10 May 1843, Audubon rode into a U. S. Army encampment along the Missouri River below Council Bluffs, Nebraska. He had just introduced himself to the officer-in-charge, when "I looked up and saw the first Yellow-headed Troupial alive that ever came across my own migrations. The captain thought me probably crazy, as I thought Rafinesque when he was at Henderson; for I suddenly started, shot at the bird, and killed it" (Audubon et al. 1897: 1: 480).

${ }^{20}$ CSR to Zaccheus Collins, 12 August 1818: Boewe 2011-CD: letter 125.

21 "In 1820 I described in my Annals of Nature, sp. 5, the spalax vittata, with striped back, \&c. ...This last however has been seen also by my friend Audubon, who first made it known to me ..." (Rafinesque 1832: 61).

22 Rafinesque's (1818b: 446) description of the "Bluish shrew mouse ... Sorex cerulescens", was: "Body bluish above, white beneath, ears large gray, tail gray, as long as the body. Length 4 inches." This "species" does not appear in his field notebook.

${ }^{23}$ Boewe 2011-CD: letter 125; Rafinesque listed his "Lemmus albovittatus" as a "Sorex albovittatus".

${ }^{24}$ Rafinesque's (1818b: 446) description of the "Mole lemming . . Lemmus talpoides" (SIA-RU 7250: 17: entry no. 225) was: "Dark gray, belly whitish, tail one-sixth of total length, ears small. Length 4 inches. Vulgar name, ground mice or snow mice. It burrows like the mole, and burrows in winter between the snow and the ground. It lives on roots, \&c." Later, Rafinesque (1820b: 3) added that this species feeds "on roots and grass, while in the winter it burrows under the snow, at the surface of the ground, to feed on tender grass."

25 Rafinesque's (1820b: 4) description of the "Great Fox Squirrel ... Sciurus ruber" (SIA-RU 7250: 17: entry no. 228) was:

Entirely of a fine brick red colour, except the belly, which is whitish, ears beardless - The largest of all the American Squirrels; total length over two feet. Is it a variety of Sc. vulpinus? It is found in the Missouri 
Territory, where it is called Great fox-squirrel. There are yet in the United States many unnoticed species (or varieties) of squirrels. I know already about eight of them, such as Sc.felinus, Sc. phaiopus, Sc. melanotus, Sc. lateralis, \&c. I am preparing a monography of them.

Rafinesque's "monography" of tree squirrels was never published.

${ }^{26}$ Rafinesque published a number of pamphlets, books, and short-lived journals that typically had small publication runs and limited circulation. For example, when Rafinesque was in Sicily, he published two volumes of Specchio delle scienze during January-December 1814; Annals of nature lasted one issue in 1820; Atlantic journal and friend of knowledge comprised eight numbers spanning spring 1832 through to winter 1833; only one issue of Western Minerva was printed in 1820 or 1821, but it was suppressed by the printer before it could be distributed.

27 This prank would have occurred during the 1843 Missouri River expedition made by Bell, Audubon, Edward Harris and Isaac Sprague. Audubon had hoped to bring young Baird along as well, but Lewis M. Squires took his place when Baird had to back out (Harris and McDermott 1951). Neither Audubon (Audubon et al. 1897) nor Harris (Harris and McDermott 1951) mentioned the incident in their published journals from that trip. I found no evidence that the "new bird" was ever published, and three research ornithologists who I asked had no knowledge of it.

\section{REFERENCES}

AMBROSE, C. T., 2010 Darwin's historical sketch - an American predecessor: C. S. Rafinesque. Archives of natural history 37: 191-202.

AUDUBON, J. J., 1831 Ornithological biography. Volume 1. Edinburgh.

AUDUBON, J. J. and AUDUBON, L., 1868 The life of John James Audubon. New York.

AUDUBON, J. J., AUDUBON, M. R. and COUES, E., 1897 Audubon and his journals. With zoological and other notes by Elliott Coues. 2 volumes. New York.

AUDUBON, J. J. and BACHMAN, J., 1845-1854 The viviparous quadrupeds of North America. New York.

BAIRD, S. F., 1857 Reports of explorations and surveys, to ascertain the most practicable and economical route for a railroad from the Mississippi River to the Pacific Ocean. Volume 8. General report upon the zoology of the several Pacific railroad routes. Part I. Washington, D.C.

BOEWE, C., 2011 The life of C. S. Rafinesque. A man of uncommon zeal. Philadelphia.

CALL, R. E., 1895 The life and writings of Rafinesque. Louisville.

CALL, R. E., 1899 Ichthyologia Ohiensis or natural history of the fishes inhabiting the River Ohio and its tributary stream by C. S. Rafinesque. A verbatim et literatum reprint of the original, with a sketch of the life, the ichthyologic work, and the ichthyologic bibliography of Rafinesque. Cleveland.

COUES, E., 1876 Some account, critical, descriptive, and historical, of Zapus hudsonius. Bulletin of the United States Geological and Geographical Survey of the Territories, second series, 1: 253-262.

CRAMER, Z., 1817 The navigator. Ninth edition. Pittsburgh.

DESMAREST, M. A. G., 1822 Mammalogie ou description des espèces de mammifères. Seconde partie. Paris.

GILBERT, B., 1999 An "odd fish” who swam against the tide. Smithsonian magazine 19 (10): 112-114, 116, 117, 119-125.

HARRIS, E., and McDERMOTT, J. F., 1951 Up the Missouri with Audubon. The journal of Edward Harris. Norman.

HOLDER, C. F., 1910 Spencer Fullerton Baird, Geologist, 1823-1887, pp 269-281 in JORDAN, D. S. (editor), Leading American men of science. New York.

JORDAN, D. S., 1877a Concerning the fishes of the Ichthyologia Ohiensis. Bulletin of the Buffalo Society of Natural Sciences 3: 91-97.

JORDAN, D. S., 1877b Review of Rafinesque's memoirs on North American fishes. Bulletin of the United States National Museum 9: 1-53.

JORDAN, D. S., 1886 Rafinesque. Popular science monthly 29: 212-221. 
KLEBER, J. E. (editor), 1992. The Kentucky encyclopedia. Lexington.

LEA, I., 1870 A synopsis of the family Unionidae. Philadelphia.

MARKLE, D. F., 1997 Audubon's hoax: Ohio River fishes described by Rafinesque. Archives of natural history 24: $439-447$.

MERRILL, E. D., 1949 Index Rafinesquianus. Jamaica Plain.

ORD, G., 1815 Zoology of North America, pp 290-361 in GUTHRIE, W.[,FERGUSON, J., KNOX, J., and ORD, G.], A new geographical, historical, and commercial grammar; and present state of the several kingdoms of the world. Volume 2. Philadelphia.

OSGOOD, W. H., 1909 Revision of the mice of the American genus Peromyscus. North American fauna 28: 1-267.

PENNELL, F. W., 1942 The life and work of Rafinesque. Transylvania College bulletin 15 (7): 10-70.

PETIT, R. E., 1985 The trivalved mollusk. Shells and sea life 17: 132-133.

PILSBRY, H. A., 1917 Rafinesque's genera of fresh-water snails. The nautilus 88: 109-114.

PREBLE, E. A., 1899 Revision of the jumping mice of the genus Zapus. North American fauna 15: 1-41.

RAFINESQUE, C. S., 1814 Précis des décourvertes et travaux somiologiques ou zoologiques et botaniques. Palermo.

RAFINESQUE, C. S., 1818a Discoveries in natural history, made during a journey through the western region of the United States. American monthly magazine and critical review 3: 354-356.

RAFINESQUE, C. S., 1818b Further discoveries in natural history made during a journey through the western region of the United States. American monthly magazine and critical review 3: 445-447.

RAFINESQUE, C. S., 1818c Further account of discoveries in natural history, in the western states. American monthly magazine and critical review 4: 39-42.

RAFINESQUE, C. S., 1818d General account of the discoveries made in the zoology of the western states. American monthly magazine and critical review 4: 106-107.

RAFINESQUE, C. S., 1819a Result of the botanical discoveries made in the western states. American monthly magazine and critical review 4: 207-208.

RAFINESQUE, C. S., 1819b Description of a new genus of fluviatile bivalve shell, of the family of Brachiopodes. American monthly magazine and critical review 4: 356.

RAFINESQUE, C. S., 1819c Prodrome de 70 nouveaux Genres d'animaux découverts dans l'intérieur des États-Unis d'Amérique, durant l'année 1818. Journal de physique, de chimie, d'histoire naturelle et des arts $\mathbf{8 8}$ : $417-429$.

RAFINESQUE, C. S., 1820a Fishes of the Ohio. First part. Thoracic fishes. Western review and miscellaneous magazine 1: 368-377.

RAFINESQUE, C. S., 1820b Annals of Nature or Annual Synopsis of New Genera and Species of Animals in North America. Volume 1. Kentucky.

RAFINESQUE, C. S., 1820c Monographie des coquilles bivalves fluviatiles de la rivière Ohio, contenant douze genres et soixante-huit espèces. Annales générales des sciences physiques, Bruxelles, 5: 287-322, plates LXXX-LXXII.

RAFINESQUE, C. S., 1820d Fishes of the River Ohio. Western review and miscellaneous magazine 2: 299-307.

RAFINESQUE, C. S., 1820e Fishes of the River Ohio. Western review and miscellaneous magazine 3: 165-173.

RAFINESQUE, C. S., 1820f Fishes of the River Ohio. Third Part. Apodial fishes. Western review and miscellaneous magazine 3: 244-252.

RAFINESQUE, C. S., 1820g Ichthyologia Ohiensis, or natural history of the fishes inhabiting the River Ohio and its tributary streams, preceded by a physical description of the Ohio and its branches. Lexington.

RAFINESQUE, C. S., 1832 On the moles of North America and two new species from Kentucky. Atlantic journal and friend of knowledge 1: 61-62.

RAFINESQUE, C. S., 1833 Sorex dichrurus. n. sp. of shrew. Atlantic journal and friend of knowledge 1: 175-176. 
RAFINESQUE, C. S., 1836 A life of travels and researches in North America and south Europe, or outlines of the life, travels and researches. Philadelphia.

SMITH, D. L., and SWICK, R. (editors.), 1997. A journey through the west. Thomas Rodney's 1803 journal from Delaware to the Mississippi Territory. Athens.

WOODMAN, N. 2012. This shrew is a jumping mouse (Mammalia, Dipodidae): Sorex dichrurus Rafinesque, 1833 is a synonym of Zapus hudsonius (Zimmermann, 1780). Proceedings of the Biological Society of Washington 125: 308-316.

WOODMAN, N. 2015. Louisville, Kentucky, is the type locality for the white-footed mouse, Peromyscus leucopus (Rafinesque, 1818) (Mammalia: Rodentia: Cricetidae). Proceedings of the Biological Society of Washington 128: 152-163.

Received 22 June 2015. Accepted 13 August 2015. 